\title{
Dynamic Capabilities for Sustainability: Revealing the Systemic Key Factors
}

\author{
Luciana Oranges Cezarino ${ }^{1}$ - Marlon Fernandes Rodrigues Alves ${ }^{2}$ • \\ Adriana Cristina Ferreira Caldana ${ }^{3} \cdot$ Lara Bartocci Liboni $^{3}$ (iD
}

(C) Springer Science+Business Media, LLC, part of Springer Nature 2018

\begin{abstract}
By applying systems thinking theory to capabilities literature, this paper examines the factors that support the development of dynamic capabilities towards sustainable management. For such, we conducted an in-depth single case study using Soft System Methodology (SSM) in an energy organisation from an emerging economy. Our analysis of the last twenty years of operation revealed that the organisation has developed new ways to change and adapt in a disturbing environment by integrating sustainability into three factors: (1) integrative strategy (green products, biodiversity, organic processes and self-sufficient electricity), (2) sustainable culture (sustainable mindset, environmental awareness, learning orientation and decision-making processes) and (3) organisational routines for innovation (new green processes and products, partnerships/alliances and knowledge management). Our results extend the literature by raising a conceptual framework of the fundamental dimensions of dynamic capabilities for sustainability. This is the first study that connects systems thinking and dynamic capabilities theories applied to sustainable management.
\end{abstract}

Lara Bartocci Liboni

lara.liboni@gmail.com

Luciana Oranges Cezarino

lcezarino@gmail.com

Marlon Fernandes Rodrigues Alves

marlon.alves@ifsp.edu.br

Adriana Cristina Ferreira Caldana

caldana@usp.br

1 Faculty of Business and Management, Federal University of Uberlândia (FAGEN/UFU), Avenida João Naves de Ávila 2121, Uberlândia, MG 38400-902, Brazil

2 Federal Institute of Education, Science and Technology of São Paulo (IFSP), Rodovia Washington Luís Km 235, São Carlos, SP 13565-905, Brazil

3 School of Economics, Business Administration and Accounting at Ribeirão Preto, University of São Paulo (FEA-RP/USP), Avenida dos Bandeirantes 3900, Ribeirão Preto, SP 14040-905, Brazil 
Keywords Organisational capabilities $\cdot$ Environmental capabilities · Eco-capabilities · Corporate social responsibility $\cdot$ Systems thinking

\section{Introduction}

Sustainability has been pushed to the forefront of organisational strategies and politics as the world wakes up to the impacts of the modern consumer and industrialisation on climate change (Hamin and Gurran 2009; Zhao 2010; Yigitcanlar and Teriman 2015; UNGC 2015; United Nations 2017; UNGC 2018). It assumes a central role on possible new ways to foster sustainable development, especially by focusing on the renewable energies industry (Birol 2010; Moallemi et al. 2014).

This new paradigm implies profound changes in current production systems (Belico and Silveira 2000, Muff et al. 2017; Reyers et al. 2017), where managers have to assume attitudes and actions that change behaviours, culture, and interests (Mebratu 1998) to bring sustainability to the core of business innovation (Werbach 2010, p. 67). Companies that are unable to develop this capacity will have difficulties surviving (Esty and Winston 2009). Capabilities to make sustainability more dynamic and integrated with strategies, transforming it into a business asset, have yet to be studied (Liboni-Amui et al. 2017).

If we assume that social systems are capable of encouraging self-maintenance based on the throughput of resources from their environment as a living cell (Boulding, 1956), then it is reasonable to consider organisations as open systems that establish the homeostasis of their resources with the changing environment. Adaptive behaviour is equivalent to the behaviour of a stable system, which is endowed with dynamic stability (François 2004; Ashby 1958, 2013). Dynamics capabilities are the change process that companies experience to survive (Eisenhardt and Martin 2000; Teece et al. 1997), thus equating the learning process (Zollo and Winter 2002) to system viability (Beer 1989).

Moreover, sustainable development is a recent imperative for industry as the new key source of innovations for the sugarcane energy business (Lubin and Esty 2010). All kinds of stakeholders care about sustainability-related opportunities and how the industry can design such strategies through technology processes and innovation. The findings also represent a foundation for further theoretical developments (e.g., deductive approaches) of the relationship between sustainability and strategic management in this industry (Spetic et al. 2012).

For that, this paper analyses the behaviour of a social system by exemplifying it as an industrial organisation in Brazil. The point is to understand how dynamic capabilities have lead towards sustainability management. The biomass energy industry was chosen because of its relevance to the Brazilian economy, in terms of the generation of wealth and employment, and for representing a cleaner production industry.

In a practical view, the paper contributes to emphasis of the original fit of SSM to deal with the theory of dynamic capabilities as a complex problem. There is a lack of studies that connect dynamic capabilities with systems thinking (Chakrabarty and Wang 2012; Boscoianu et al. 2018). SSM can produce insights to remark relations that no linear method can achieve. The possibility of critical thinking by structuring the ambiguous problem situations (Georgiou 2012), as in this case, seems to provide a good opportunity for elucidating new solutions and paths for organisations searching for sustainable development. SSM steps, by revealing insights through the root definition of the system (Checkland and Scholes 1999), enable the participation process of investigators and stakeholders by conjoining opinions with logic consensus and system transformation. 


\section{Conceptual Background}

\section{System Thinking and Sustainable Development}

There is no universally accepted definition of sustainability. The discussions arise from the concept of the triple bottom line (TBL), which deals with the positive results regarding economic, social and environmental dimensions - the latter being the hallmark of the first use of the term "sustainable development" (Elkington 1997; Brundtland 1987). Since 2015, the Sustainable Development Goals (UNGC 2015) are enriching society with an even broader approach. When transposing this idea to the business level, it can be defined as the needs of a firm's direct and indirect stakeholders without compromising its ability to meet the needs of future stakeholders (Dyllick and Hockerts, 2002) by striving to both recover and develop the resources they consume today (Ehnert 2009) and create value in the long term (Chakrabarty and Wang 2012).

Therefore, many changes are required to enable companies to adapt to a sustainable development model; one of them is identifying environmental changes and built resilience (Fiksel 2006). Organisations achieve success because of their ability to constantly change and adjust their resources (Burnes 1996, Batista et al., 2013). As system theory may consider that it is to the rate of change, rather than to the changes themselves, that organisations have to adapt (Beer 1981), equilibrium refers to the homeostasis property of systems to adapt to external disturbances (contextual variety) and restore their point of balance in order to maintain stability and survive (Ashby 1958).

The systems' challenge is to establish adaptations that are consistent with sudden, ambiguous and discontinuous changes since complexity requires requisite variety (Bar-Yam 2004). Organisations, as social systems, face complexity regarding their surroundings in the construction of their attempt to survive or be viable (Beer 1984) while using their resources and capabilities. Different aspects can provide the sense of viability in a system as emergence, selforganisation, identity and reclusiveness (Holman 2010, Stokes 2004, Harries-Jones, 1995, Senge 1990, Ashby 1958, Beer 1984).

Stakeholders, as providers, clients, employees and members of the local community, appear to be an important pressure on sustainable practices. As social systems, organisations must develop requisite variety to engage such changes by integrating strategies and business models. Further, they must take action towards sustainable practices that must pass through, necessarily, changes and adaptations, so to become a capability that is able to readapt dynamically over time (Hart 1995).

A capability is considered dynamic when it enhances a firm's ability to make decisions, solve problems, identify opportunities and threats and modify existing resources (Barreto 2009). Dynamic capacity is 'the capacity of an organisation to purposefully create, extend, and modify its resource base' (Helfat 2007, p. 4). Eisenhardt and Martin (2000), as well as Teece et al. (1997), assert that performance and competitive advantage result from the reconfiguration of a firm's resources in congruence with the environment and whose organisational processes are the origin point.

Rooted by the resource-based view (Barney 1991), capabilities theory tackles this challenge by reasoning that it is factual that organisations consistently operating in a dynamic environment create and recombine their resources in new ways. Teece (2007) also acknowledges that a dynamic capability could become a best practice over time. According to Zollo and Winter (2002), dynamic capabilities have to be developed through a set of activities and cognitive 
processes focused on the organisation's own routines. For Shuen et al. (2014, p. 7), strategy, capabilities and the business environment coevolve.

Promoting sustainability into an organisational dynamic capability is a challenge that companies will have to deal with if they want to be competitive, naturally passing by being environmentally and socially responsible (Liboni-Amui et al. 2017). It is in this sense that there arises the concept of eco-capacity, as 'a firm's capacity to deploy environmental human, business, and technology resources to enhance firm performance and conserve the natural environment' (Gabler et al. 2015).

\section{Dynamics Capabilities towards Sustainability}

Literature can also clarify organisational aspects that, generally, can promote sustainability through dynamic capability in organisations.

Schrettle et al. (2014) operationalise the sustainability challenge by defining the relevant drivers of sustainability and classifying them into two groups: exogenous (external) and endogenous (internal) drivers. The endogenous drivers are the organisational factors representing internal forces: strategy, culture and resource base.

The strategy represents an important factor because one of the major challenges is the integration of sustainability principles into the overall firm strategy (as the objectives, vision and mission, for instance). Organisations often tend to see sustainability as a separate aspect of core strategy (Etzion 2007). A proper implementation of a sustainability strategy should become a driver for the development of capabilities as organisational resources (Russo and Fouts 1997).

The second internal driver that Schrettle et al. (2014) considered is the culture. Cultural influences, such as motivation, information dissemination, management commitment and a longer-term horizon, represent important drivers of ecological responsiveness.

For the third driver, Schrettle et al. (2014, p.77) confirmed that 'the provision of adequate resources drives a firm's operations including sustainability initiatives'. Physical capital resources, such as technology and human capital, are important factors that drive innovation for sustainability, making this dynamic. Specific skills are a part of the resources of the firm, which influence the success of sustainability initiative implementation. 'Organisations that have already obtained a track record in sustainability by gaining experience and important capabilities in sustainability management are better positioned to engage in further sustainability initiatives' (Schrettle et al. 2014, p. 77).

In the same study, the authors identified critical focus themes on organisations' agendas that are encompassed by sustainability efforts, such as new technologies to make manufacturing processes more sustainable and the development of green products.

For Gabler et al. (2015), in order to build an eco-capability it is necessary to have an environmental orientation since the most effective business strategy must be aligned with the corresponding orientation. Environmental orientation involves knowledge of the natural environment and its role in the business landscape and considers stakeholders, such as local communities. Environmentalism, similar to other knowledge assets, is a part of an organisation's culture and climate (Lindahl 2006).

Besides environmental orientation, Gabler et al. (2015) consider a company's ability to innovate as an important factor with which to build an eco-capability. The improvement of products and processes and organisational innovativeness cannot only reflect something that is new to the industry, to the customer and to the environment, as it is also an important dynamic capability itself (Gebauer 2011). 
Hofmann et al. (2012) affirmed that the adoption of advanced technology, collaboration experience with suppliers and customers and innovative capacity are capabilities that promote an organisation's' ability to continuously implement environmental management practices and environmental collaboration. For Beske (2012), sustainable organisations are often very innovative, such as organisations that have a highly developed dynamic capability orientation. Teece (2007, p. 1319) calls them 'intensely entrepreneurial'.

For Beske (2012), the key factors to achieve a dynamic capability towards sustainability are (1) orientation (sustainability and learning orientation), (2) continuity, (3) risk management and (4) proactivity. The knowledge assessment (strategic alliances and partnerships, for instance) and the coevolving are in the core of the dynamic capability (capability of developing and implementing new capabilities), besides other supply chain dimensions that Beske studied (2012).

Caldana et al. (2015) presented a framework of capabilities consistent with organisational changes towards sustainability that was inspired by the previous studies of Gabler et al. (2015) and Beske (2012). This model approaches TBL dimensions and their respective capabilities to be investigated (Table 1).

\section{Method}

Our study is part of the international project conducted by the Global Organisational Learning and Development Network (G.O.L.D.E.N 2011), carried out in partnership with the Università Commerciale Luigi Bocconi (Italy), among others. The project's members are responsible for creating a platform for cooperation and sharing knowledge about how organisations modify (and learn to modify) their business models involving corporate sustainability. The knowledge development in the project is primarily related to design change and learning-to-change initiatives. More specific, the global roll-out involves three phases: diagnostic analysis, change interventions and post-intervention measurements.

The present study can be classified as qualitative, descriptive and action research. To be more precise, it addresses a single case (Eisenhardt and Graebner 2007) that is being analysed

Table 1 Capabilities for sustainability: framework of analysis

\begin{tabular}{ll}
\hline TBL & Categories of analysis \\
\hline Economic dimension & - Sustainable view \\
& - Challenges \\
Social dimension & - Competitive environment \\
& - Investments \\
Environmental dimension & - Processes \\
& - Performance management \\
& - Communication \\
& - Changes \\
& - Sustainable view \\
& - Labour practices \\
& - Stakeholders \\
& - Sustainable view \\
& - Environmental investments \\
\hline
\end{tabular}

Source: Caldana et al. (2015) 
by SSM (Checkland 1981). The chosen company is the Balbo Group (established in 1946), which is located in the city of Sertãozinho, State of São Paulo, Brazil. With three industrial plants, it produces sugar, organic sugar, ethanol, organic ethanol, biodegradable plastic and other sugarcane products. This empirical setting seems suitable to understanding how the organisation develops a dynamic capability towards sustainability.

The sugar and ethanol energy sector represents a strategic sector for the Brazilian economy. The sugar and energy sector summed US $\$ 43.4$ billion in the 2013-2014 crop year, an increase of $44 \%$ in relation to the 2008-09 crop yield. This figure is higher than the GNP of more than 100 countries. The sector contributed US\$ 8.5 billion in taxes and moved US\$ 107 billion in the production chain, with exports summing up to US\$ 1.67 billion. Ethanol also has a significant participation in the employment level, generating about 1 million direct jobs - a figure reaching 3.6 million if indirect and informal jobs are computed (NOVACANA 2014).

Data on the company were collected from reports, its official web site and its interviews with eight managers of different departments. The following areas were addressed: 1) strategy, 2) financing, 3) R\&D, 4) operations, 5) logistics, 6) marketing, 7) personnel management, and 8) corporate, social and environmental responsibility. For a broader comprehension of the organisation, we also interviewed four different stakeholders: 1) the secretary of environment of the municipality, 2) a representative of a non-governmental organisation of the third sector that is systematically aided by the company, 3) a sugarcane supplier and 4) a representative of the main environmental regulation institution of the sector.

The interviews used a research protocol that GOLDEN developed in 2011, which was applied as a script to conduct questioning. The original protocol had more than 1000 questions and was reduced to selected categories by the study of Caldana et al. (2015), Table 1.

We used SSM to understand the problem situation, analyse qualitative data and propose key factors of dynamic capability for sustainability. SSM is a soft methodology developed from the observation that not all problems and situations faced by social systems are clear and linear for a solutions proposal (Checkland 1981). SSM was 'designed to assist in the resolution of soft issues, which are of complex nature and involve many human elements' (Martinelli and Ventura 2006, p. 163). Using conceptual models by addressing a 'systemic world' allows divergent approaches of a complex problem to be processed in cybernetics perspectives.

Cezarino et al. (2015) described the steps of SSM as follows (Fig. 1):

The choice for SSM reveals the lack of clarity about the development of dynamic capability with regards to sustainability in the case study. Not much information was available before the

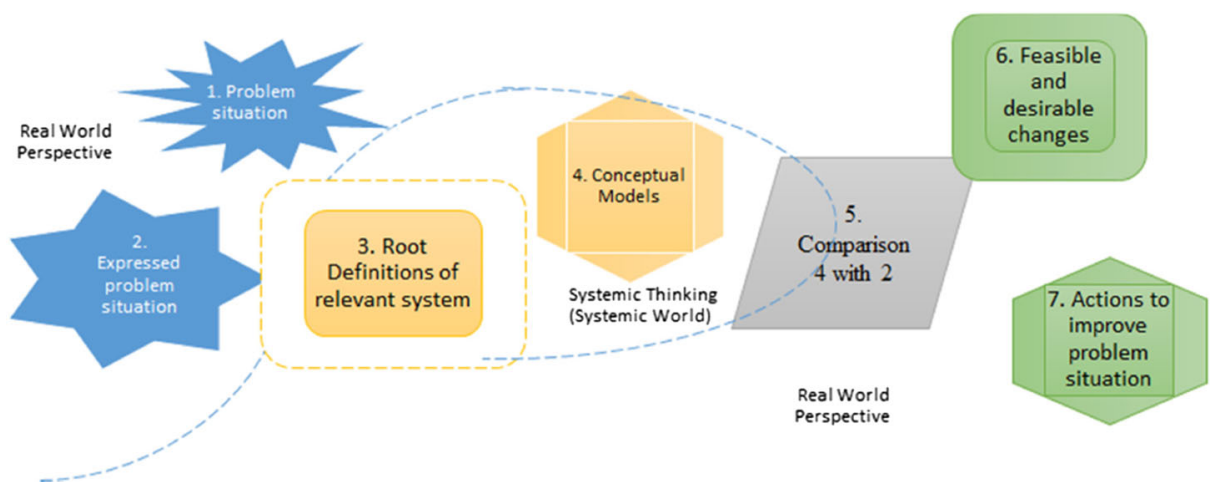

Fig. 1 SSM steps. Source: Adapted from Cezarino et al. (2015) 
data collection proceedings and the company had never formalised an internal process for deliberate learning. For that, SSM could provide the right amount of intervention, characterising by its constructionist knowledge process and the considerations of stakeholders' opinion. Step by step we could identify the process and understand its origins and trajectory among the company's change.

\section{Results and Discussion}

\section{Step 1 - The Problem Situation}

Balbo Group produces sugar, organic sugar, ethanol, organic ethanol, biodegradable plastic and other sugarcane by-products. The company's mission is to explore the sustainable agribusiness potential of sugarcane and other agricultural products. The Group has strong sustainability practices related to the production process and product innovation, as it is the world's largest organic agribusiness company.

Divided into three industrial plants, it currently has the capacity to mill 5 million tons of sugarcane supplied by more than 300 independent producers. The Balbo Group operates these lands through partnerships. The Group has benefited from the production of electricity from the sugarcane waste in its unit for 14 years, thus allowing the plant to be self-sufficient in meeting the energy needs of its industrial activities. The Group has also an organic food industry called Native that is the world's largest organic agribusiness company.

All managers reported that they are linked to sustainability in specific ways. For example, the operations manager explained that no hand harvest was used, following the proposed by the Sustainable Development Goals (SGDs) from the United Nations (UN). Personnel management described the social care provided to all families that used to work on the fields and have to be trained to find new job opportunities on the local market. Marketing revealed the need to certify food products for exportation to qualified markets, such as the United States and Europe, especially with sanitary norms and proceedings. The operations manager exposed some strategies used on the production process to reuse and minimise water and, of course, be self-sufficient in energy expenditure. Finally, Native, the organic food business unit, was created to produce and commercialise final goods, which was different from all B2B relations that Balbo has developed since.

Thus, the sustainable aspects linked to environment, economy and social dimensions were present in practical ways, but they were fragmented into different areas without a visible connection. This situation was clear until the Green Cane Project ${ }^{\circledR}$ that had the mission to relate all sustainable efforts into an emerging strategy for the company.

\section{Step 2 - The Expressed Problem Situation}

The sustainability practices of the Balbo Group are diverse and involve processes and products. Different areas were responding to their own environment, providing responses through their own resources. Operations, marketing, logistics, personnel and all of eight areas were presenting similar behaviours, but with functionally different resources; all adapting to a distressing environment looking for their equilibrium.

The Group's strategy was to shift its organic strategies towards the creation of the trademark 'Native', which has been present in the market since 1996, but was formally traded in 2000. 
Native is an important branch of the Group as it allows the company to focus on higher valueadded products rather than solely producing commodities. Native produces organic sugar, chocolates, coffees, cookies, juices, soy beverages, cereal bars, breakfast corn flakes and chocolate powders, among other organic food products.

Native products have to meet the criteria of being organic, healthy and tasty. The products also have the most restrictive environmental and production certifications, which enable the company to consolidate its project called the Green Cane Project ${ }^{\circledR}$ involving the production of sugarcane without the presence of agrochemicals. Native's suppliers have to be certified as organic and with this strategy the company ends up developing a whole chain of suppliers within the parameters of sustainable agriculture.

Besides the aspects of healthy food and food security provided by organic products, studies carried out by EMBRAPA ${ }^{1}$ researchers showed that biodiversity has increased in the cultivation areas involving Native products. In those areas operated by the Green Cane Project@, one can find more than 339 species of the Brazilian fauna, such as mammals, birds, reptiles, and amphibians, which has only been possible due to organic agriculture.

The Group's companies are self-sufficient in the production of electricity. The surplus of produced energy is supplied to the state's energy distribution company (CPFL Energy Companhia Paulista de Força e Luz). The Balbo Group is a pioneer in Brazil in the coproduction of electricity from sugarcane waste. It produces enough energy to supply the demand of a city with a population of 80,000 . The Group plans to enlarge its energy coproduction activities and has commercialised carbon credits from three harvests.

In-house technological research has allowed for the use of new products, such as biodegradable plastic and organic products. These products promote sustainability and are underpinned by the principles of using fewer natural resources and creating less environmental impact.

The solid and liquid organic effluents from industrial processes are recycled for agronomic applications. The global system of raw sugarcane production and harvest, established in 1987, is one of the most important applications of agronomic research and mechanisation. By harvesting without crop burning, this new production system allowed for the optimisation of the use of organic industrial waste as a source of nutrients and the practice of organic composting in rotating crop systems. These practices contributed to the Group being awarded the status of a large-scale organic sugarcane producer. According to major international certification agencies, the Group is the world's largest organic agri-business company.

As a predecessor to its Green Cane Project ${ }^{\circledR}$, in 1987, the Group implemented a reforestation program using native Brazilian species. The main objectives of the program were the creation and integration of islands of biodiversity in agricultural areas, the protection of water resources and the improvement of conditions for wildlife.

Dust caused by heavy vehicle and machinery traffic is another concern of the Green Cane Project@. All internal tracks and roads are watered before receiving more traffic. The majority of these routes are already covered with grass. As an additional result of organic practices and reforestation, streams have formed naturally within agricultural areas. This process would have been unimaginable during the time of traditional agricultural practices. The soil is covered by organic waste, so rainwater does not completely evaporate and is able to infiltrate the soil, thereby feeding these extremely clean local streams that are part of the effort to recreate the elements of nature. The environmental monitoring of agricultural areas requires evidencebased knowledge of land use and land cover, which the company mapped via satellite images

${ }^{1}$ EMBRAPA: Brazilian Agricultural Research Corporation, connected to the Ministry of Agriculture. 
and fieldwork. A geographical information system (GIS) was developed for the collation and management of agricultural and environmental data, including land use and land cover.

Important environmental actions taken by the company include landscape and habitat diversification; the creation of new areas of native vegetation; the protection, maintenance and enrichment of existing forest areas; the development of ecological corridors; wildlife management; improvement of water quality and availability, as well as accessibility to fauna; the abandonment of sugarcane burning and fire practices (harvesting raw sugarcane); the total cessation of the use of agrochemicals (chemical inputs); the exclusive use of organic fertilisation (pesticides and other chemical substances are no longer used); biological control of pests; soil management; erosion control; the increased capacity for water to infiltrate the soil; the increased availability of water in several sub-basins; the banning of wood harvesting or collection; enforcement of hunting bans; the installation of physical barriers to control unauthorised access to preserved areas and environmental education for employees.

Through the Green Cane Project ${ }^{\circ}$, the Group has greatly reduced its work force in the fields, as machines conduct $90 \%$ of the harvest. No new rural workers will be employed, and the remaining workers will be trained and reallocated to other jobs within the company. The growth of mechanisation has increased the demand for qualified employees, and the company has invested in professional development, qualification and training. However, the demand exceeds the in-house process of developing internal talent. Thus far, 100 employees from the agricultural sector have been trained to undertake jobs in other areas within the company.

Unlike companies with environmentally or socially controversial activities and who base their sustainability actions in isolated projects, sustainability is a strategic pillar in Native and is the core business of the company.

There is also a strong concern about working conditions, social assistance projects for employees and their families, as well as education projects for community youth.

Therefore, considering all of the information mentioned above, the Group understood that sustainability could add market value to sugar and ethanol, which are considered commodities of low aggregate value. The sustainable processes were implemented as a way to improve productivity and quickly respond to the social demand for engagement with environmental regulations and concerns.

\section{Step 3 - Root Definitions of Relevant Systems}

By analysing the whole system, it was possible to comprehend the root definition of SSM. The company is trying to achieve better performance in sustainable (economic, social and environmental) outputs through its internal factors (strategy, culture and resource base) from inputs of exogenous (external) drives as regulation and stakeholder's pressures.

Bergvall-Kåreborn et al. (2004) stated that the six elements of CATWOE would be traceable in a well-formulated root definition and tested by examining a range of root definitions and relating them to the happenings to find out whether any of the elements were missing and, if so, whether the absence had mattered.

CATWOE is presented below.

- $\mathrm{C}$ (costumers): the focus of the analysis is sustainability; therefore, all stakeholders are considered to be clients of the system. The municipalities that use the electricity that is coproduced by the company and CPFL Energy, which distributes the energy; employees; cooperatives that trade sugar and ethanol; companies that buy sugarcane products (e.g., the 
cosmetic company Natura buys organic ethanol); sugarcane producers; the government and the local community.

- A (actors): the main actors concerned with sustainability practices are the directors of the company, especially the CEO, who makes most of the decisions.

- $\mathrm{T}$ (transformation process): $\mathrm{T}$ represents the purposeful activity to be modelled and expressed as a transformation process. Traditionally, $\mathrm{T}$ has been formulated as transformation of some input to some output: Input $-\mathrm{T}->$ Output (Bergvall-Kåreborn et al. 2004), the basic transformation process of the analysed system is the creation of processes and products that promote sustainability. The main objectives of these sustainability practices are adding market value.

"Balbo adding value to products and process to survive in a greener environment"

- W (Weltanschauung - shared vision): the shared vision is represented by the company's strategic decision to implement many sustainability practices, which helped to integrate sustainability into the management model by constructing a dynamic capability towards sustainability.

- $\quad \mathrm{O}$ (owner): the owners of the company;

- E (environmental constraints): the company has a strong focus on financial returns, around which the system is organised. Any discussion about sustainability involves how it can reduce legal actions or generate higher profits. However, this focus does not restrict the capacity of the company to turn sustainability into a dynamic strategy that creates market value and effective environmental gains.

Using the categories proposed by Caldana et al. (2015), Table 2 structures the qualitative data of interviews with the managers.

Table 2 Qualitative data of interviews

\begin{tabular}{|c|c|c|}
\hline \multicolumn{2}{|l|}{ Topics } & Description \\
\hline \multicolumn{2}{|c|}{ Sustainable view } & $\begin{array}{l}\text { The conscious need to change is clear in all managers' statements, } \\
\text { function areas have developed and changed basic resources to } \\
\text { overcome environment turbulence. }\end{array}$ \\
\hline \multirow[t]{6}{*}{ Economic } & Business environment & $\begin{array}{l}\text { The environment approaches all areas, but marketing in } \\
\text { particular reveals the need to certify goods and position } \\
\text { Native as a top seller in the organic market. }\end{array}$ \\
\hline & Process & $\begin{array}{l}\text { Self-sufficiency in biomass energy consumption, minimisation } \\
\text { of water use, mechanised harvest process. }\end{array}$ \\
\hline & Performance & $\begin{array}{l}\text { Positive financial results indicate that the group is above } \\
\text { average in the sugarcane sector in Brazil. }\end{array}$ \\
\hline & Communication & $\begin{array}{l}\text { The Cana Verde Project provides a network of information between } \\
\text { different areas }\end{array}$ \\
\hline & Changes & $\begin{array}{l}\text { The Cana Verde Project has conveyed to all players that the challenge } \\
\text { reaching sustainability was a short-term effect. }\end{array}$ \\
\hline & Labour practices & Employees receive special attention in the transition of mechanised \\
\hline Social & Stakeholders & $\begin{array}{l}\text { harvest, in terms of training and reemployment. The social agency } \\
\text { declared that this a national problem, induced by environment } \\
\text { regulation and few companies are acting against it. }\end{array}$ \\
\hline Environmental & $\begin{array}{l}\text { Environmental } \\
\quad \text { (practices, investments, } \\
\text { performance, challenges) }\end{array}$ & $\begin{array}{l}\text { Certifications, better quality of life for employees, maintenance } \\
\text { of original forest areas, permanent preserved areas (APP), increase } \\
\text { in genetics to improve botanic performance are aspects of the } \\
\text { environment that are addressed by Balbo management. }\end{array}$ \\
\hline
\end{tabular}


Below is the key information from stakeholders' interviews (Fig. 2). All of the stakeholders commented on the environmental orientation and commitment of the organisation, which is visible through the projects developed in organic agriculture and raw cane harvesting. Stakeholders know the project and see the organisation as innovative in this regard. The mayor's environmental secretary emphasised the importance of the company in the history of the municipality and the commitment to education projects in partnership with the public sector and NGOs. The environmental regulator, as well as the city hall, confirmed the company's proactive and responsive attitude towards its environmental practices. The certification and the visibility that the project has do not allow the organisation to act in an irresponsible way. The supplier stressed the importance of the company's relationship with suppliers, but criticised the company's communication with society. He emphasised that it should expose more of their initiatives in the social and environmental area, helping even to minimise the prejudice that the national and international society has of the biofuel producers due to the historical burning of sugarcane. The third sector institution, which cares for needy children, highlighted the social role of the organisation, which systematically assists some non-governmental institutions. The projects of environmental education and the relation that the company has with the employees was another point of prominence in the NGOs' comments.

\section{Step 4 - Building Conceptual Models}

This step allows the researcher to cross the 'real-life' limits and look into a systemic world. What can be proposed to Balbo about challenges begins by diagnosing its trajectory by Schrettle et al. (2014) according to dynamic capabilities variables, such as strategy, culture and resources.

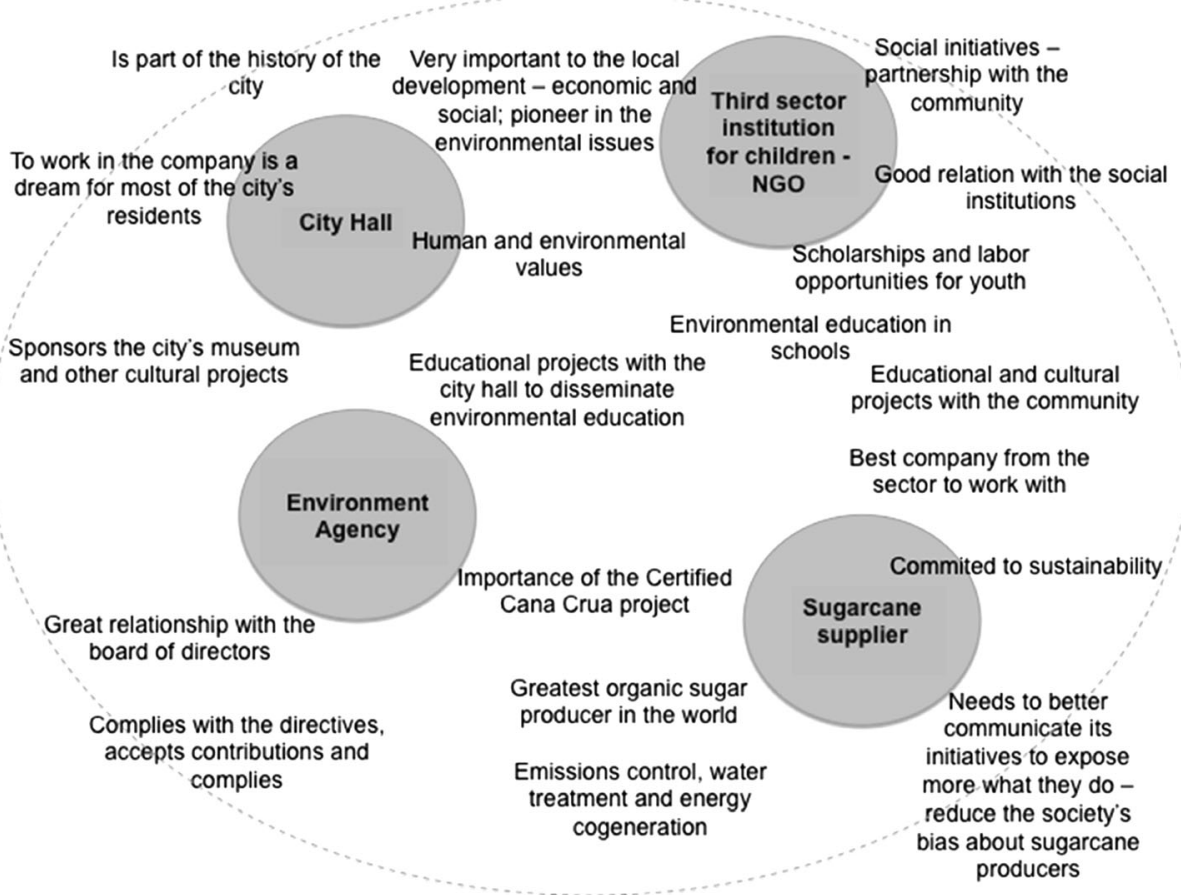

Fig. 2 Balbo's stakeholders system 
Figure 3 defines the dynamic capabilities for sustainability for the case study. The endogenous drivers are the organisational factors that represent internal forces: strategy, culture and resource base. Sustainability has to be integrated to a company's strategy. It has to be seen as a valuable resource and there must be an effort to transform it into the main company's objectives. The culture of the company must be environmentally oriented. There has to be the commitment of the managers and a strong internal awareness process so that organisational focus is on all stakeholders with a sustainability-oriented view. The decision-making process must be embedded in this culture, turning decisions into strategies aligned with the environmental orientation. The resources of the organisation have to be reorganised and reconstructed so that it can become a capability. Innovation turned out to be an important resource for environmental performance. Partnerships or strategic alliances for innovating in processes, products and in managerial innovations are a way to assess knowledge, which is a component of dynamic capabilities. To that extent, we consider that the capacity of the company to innovate towards sustainability is one of the internal factors that drives sustainability as a dynamic capability.

The environmental culture, the integrated sustainability strategies, the resources of partnerships and alliances regarding innovation and the decision-making processes gave Balbo the capacity to develop sustainability. Culture could be seen as an important factor at Balbo because the sustainability already involves the organisation's values and worldview (Weltanschauungen); this setting makes the choice of sustainable strategies a natural action. The partnership processes allow the organisation to extend its activities from adequate partnerships, thus ensuring the complementarity of knowledge that innovative business strategies require. Finally, the strategy and decision-making process involve strong support of related empirical data and transparency, including the participative process by means of collegiate bodies.

\section{Step 5 - Comparing the Systemic World with the Real World}

For all of this desirable change, the Green Cane Project® alone is not enough. It is clear that the initiative has consolidated and unified fragmented actions in functional areas, but the company needs a change within management that can facilitate the transition of a monoculture and commodity production to value-added organic food and energy goods. This could happen by the creation of a responsible office for the development and management of sustainability practices.

The creation of this office would foster a continuous debate about sustainability within an organised framework that is integrated into the business strategy. In a strategy vision, the office would work as a place to conjoin all sustainable practices provided by the eight functional areas of the company. The office would develop specific indicators to approach environmental, economic and social dimensions, but using as the culture and resources that the company already presents as a strategy. The metrics could take some time to be developed and could work in a greater interrelationship, as suggested in Fig. 3. Sustainable metrics can be contradictory when it comes to cost reduction and an increase of the quality of materials and ingredients for organic food.

The company could invest resources and efforts in the development of mechanisms, such as sustainability indicators (e.g., Global Reporting Initiative - GRI) and social balance to assist in the management and control of sustainability practices. The creation of a code of conduct and a sustainability report are also actions to be suggested to the 

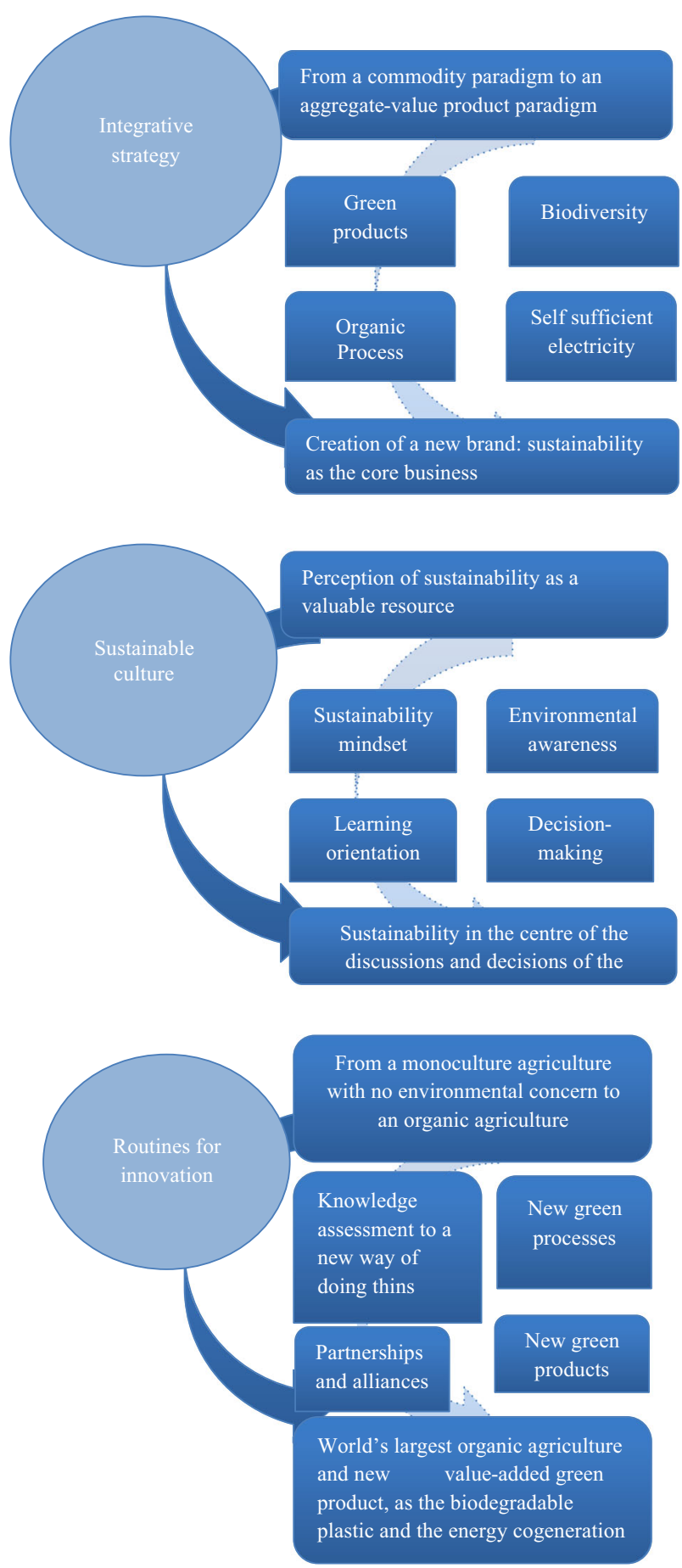

Fig. 3 Balbo Group - conceptual models 
company. It would also be relevant for the company to invest more in innovative social projects and enhancing existing efforts to train employees is also a desirable and viable alternative.

\section{Step 6 - Desirable and Feasible Changes}

In order to formalise the role of sustainability as a dynamic capacity in the company, as well as the organisational factors conditioning it, we started by analysing the environmental changes because these dynamic capacities allow the organisation to intentionally reconfigure its resources according to the changes.

The two main changes faced by the Balbo Group are the deterioration of the sugar market conditions and the society's growing pressure for a less harmful model of agribusiness to the environment.

In view of this scenario, over the past 20 years the Balbo Group has responded by shifting its profit source towards higher value-added products. With regard to the strategy, the question is always to know the best choice, and in the case of the Balbo Group, this was not different: Which is the best way to have higher value-added products? The answer was within the company itself.

Sustainability was already a latent issue in the company, even before gaining today's dimension. An example of this is the ECO-92 prize awarded to the company in an epoch when the sugar energy sector was characterised by labour practices that were considered inhumane and environmentally deplorable. In addition, it was through sustainability that the Balbo Group could recompose its resource bases to become more competitive.

The balancing between sugar market dynamics, which is a commodity, and value-aggregate products (e.g., biodegradable plastic, natural wax, thermal-electric sources using sugarcane byproducts and the organic food business) has enabled the company to balance its volume and profit margin in order to establish itself as one of the most competitive companies in the sector, with sustainability being the basis for this process.

For that, it is proposed three main actions:

- The creation of a Sustainability Office;

- The development of Sustainability metrics;

- A committee to monitor indicators.

The first action should be inspired as a parallel body of directors aside the CEO status in Balbo's organizational structure. This would elevate the condition of compliance needs for a vocational effort for high management and for all employees.

Metrics should correlate dimensions of sustainability with strategy, culture and resources, making a roll of relevant indicators that would increase productivity in a new way of achieving sustainable development. Finally, the committee would integrate different stakeholders as people from neighbouring communities, employees' associations, municipality agents and any environmental protection organisation. Beyond that, the committee can also engage different functional managers to bring strategy indicators close and feasible to operational areas.

\section{Step 7 - Actions to Improve the Problem Solution}

The last step of SSM return to the initial problem to associate it with the feasible solutions proposed on the past step. As described, Balbo has major potential in sustainable developing 
because it is a high environmental impact operation, produces clear energy, produces a very essential good to human feeding (sugar) and because it has developed a large organic food manufacturer. For that, Balbo's sustainable development is almost inherent to its survival.

However, the interviews have exposed that actions are connected by one project, the Green Cane Project ${ }^{\circledR}$, to reduce fragmented efforts in the functional areas.

This reaction of the company is clearly a way to gain equilibrium and react to the exigent environment that the functional areas have been through. Certifications, environmental regulation, social laws and the market pressure for eco-efficiency/innovation are just examples that functional areas have been reacting to the variety of their own environment as subsystem.

Dynamics capabilities towards sustainability (Teece 2007; Beske 2012) consist of the looping of feedback on the evolutionary learning of this company in the market and environment. As presented in Fig. 4, dynamics capabilities are the movement of learning that makes the system works in homeostasis. Whenever (always) there is turbulence or a relevant change in the company's environment, the system reacts. What makes it different from a natural reaction by the organisation is the level of coordination that the sustainability issue is treating. According to the proposed model, dynamics capability is a motor for sustainability to receive the survival or viable status (Beer 1981). It protects the organisation under the key orientations of Beske (2012): (1) orientation (sustainability and learning orientation), (2) continuity, (3) risk management and (4) pro-activity. Another aspect about the co-evolving (Beske 2012) is in the core of this model, where stakeholders can participate in the decision-making process inside the sustainability committee.

The Sustainability office is responsible for politics development, based in the premises of the company's vocation and suggested by Schrettle et al. (2014): strategy, resources and culture. The office would develop the indicators and its metrics based on periodic meetings with stakeholders engaged in the committee. After a certain period of time (six months, for example) the metrics and the results of indicators can be reevaluated and readapted as an open system (Fig. 5).

From the system perspective, root definitions are revisited to the dynamic process of developing dynamics capabilities to sustainability based on Balbo's case. Some important features of system theory arise.

Regarding Balbo's integrative strategy (first identified as its dynamic capability), two main aspects relate to system and cybernetics theory: emergence and Identity. Emergency, order

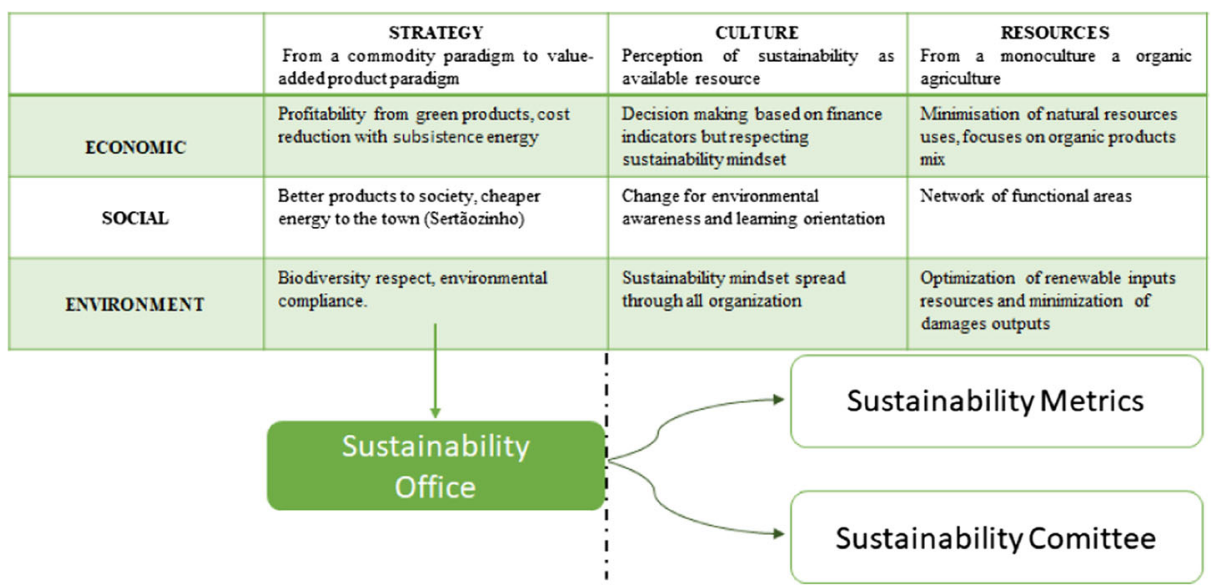

Fig. 4 Balbo Group - comparing the systemic world with the real world 


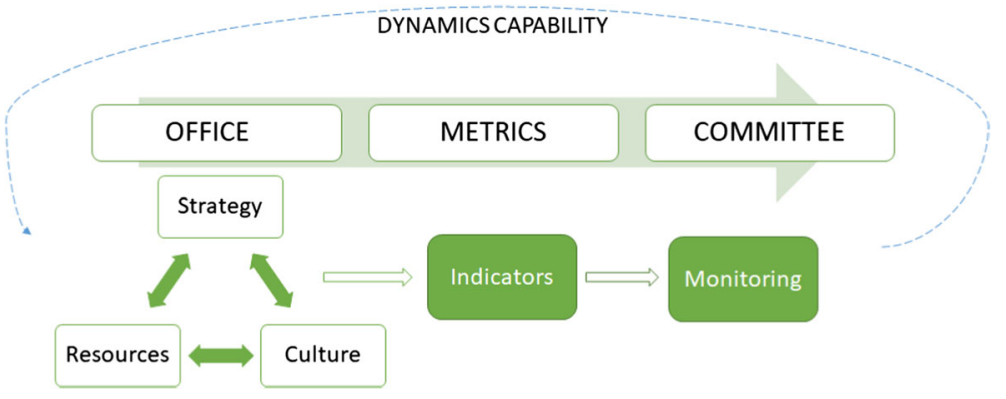

Fig. 5 Balbo Group - Dynamics capabilities towards sustainability

arising out of chaos or higher-order complexity arising out of chaos in which novel, coherent structures coalesce through interactions among the diverse entities of a system (Holman 2010) is related to strategy in Balbo Company regarding the multiple business divisions that work in commodities, energy, plastic and organic food. Different regulations, multiple supply chain management and multifaceted stakeholders turn to politics to build strategy out of chaos, integrative strategy comes as a dynamic capability for bringing order.

A system identity must be recognised. Identities are constructed and maintained through the activities of control, which in themselves are secured through circuits and networks of communication (Stokes 2004). The triad office-metrics-committee proposed in Fig. 4 reveals the body that will communicate and control sustainability office activities; the identity of a system boundary also facilitates the emergence perspective providing requisite variety to the given complexity.

The Dynamic Capability of Environmental culture is linked to recursiveness and selforganisation. Recursiveness (Harries-Jones, 1995) promotes the capacity of a system to continuously operate after feedback insertions. Self-organisation will consider the capacity to manage resources to a direct objective without a top-down driver or command. That is why culture appears as a vocation; something developed along the years throughout all organisations based in their resources and needs, not in formalised planning. For this, the company should preserve its knowledge, which is learned by doing, to improve new sustainability office strategies and change.

Learning (Senge 1990) and knowledge management (Nonaka et al. 1996) are systems capabilities to interconnect the requisite variety to system viability. They are the tools to integrate strategy (dynamic capability 1) and preserve environmental culture (dynamic capability 3 ) in the sense that tacit knowledge and past experience can allow the company to create, or learn to create, management practices in order to stimulate new ideas, new products and process design and new technology development, thus turning from the traditional commodity company to an interconnected production system.

All of these system features are indispensable for the dynamic capability development for sustainability performance output and the overall objective that is the viability of the company's whole system, according to Fig. 6.

Figure 6 shows how the Balbo Group is achieving a sustainable production system and the role of Green Cane Project ${ }^{\circledR}$ in the search for integrating fragmented efforts into a broader dynamic capability. Green Cane Project ${ }^{\circledR}$ analysis shows that sustainability actions are present in all processes and not only in some isolated activities, however, it appears by attending to different stakeholders by using fragmented resources and capabilities throughout the system. Innovation, strategy and culture are 


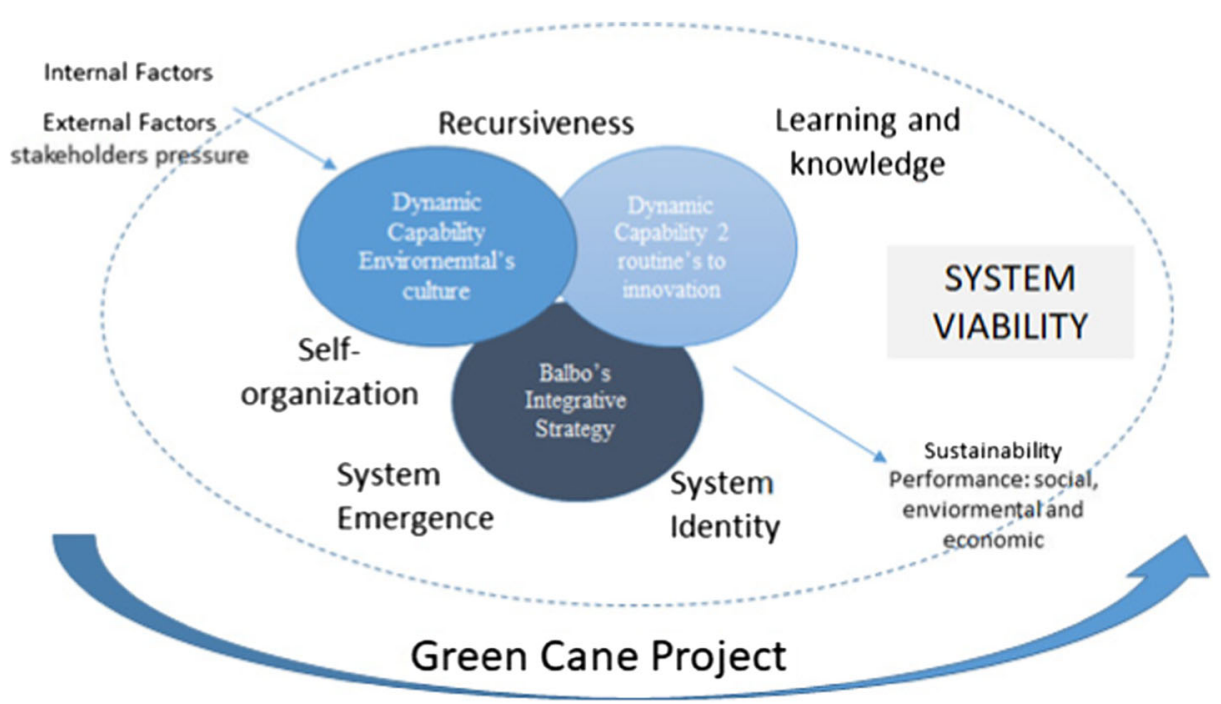

Fig. 6 Viable systems features to dynamics capabilities

supposed to be redesigned in other reach system identity, self-organisation and selfemergence by a learning process. In this organisation, the learning integration process is represented by Green Cane Project. However, a project means a temporary state of a system only; in order to maintain homeostasis in the long range, a hard and soft management structure should be built to support sustainability efforts by designing a base of resources (human and tangible assets) in a new management system. The requisite variety of the system is to attend to different stakeholders' pressures as inputs through a learning process by integrating strategy, culture and innovation in a resourcebased management structure towards sustainability performance. These three key factors are the elements that Balbo needs to integrate into a formalised learning dynamic process from the starting point of Green Cane Project, or in other words, these three factors are the challenges for dynamic capability in Balbo designing a new management system model that will be viable as long as it performances sustainability.

\section{Conclusion}

This paper analyses the behaviour of a soft system exemplifying it as an industrial organisation in Brazil. The point is to understand how dynamic capabilities have lead towards sustainable development. The result shows that SSM clarified, through its seven analyses steps, that dynamics capabilities are the looping of organisational learning that Balbo needed to give sustainability the status of a shared plan to the whole system. Sustainability actions were present and operationally effective, but a single project was not able to transform the structure of the company or prepare it for new environmental events.

This paper contributes to the finding that dynamic capability can lead to sustainable development if it is taken as high priority task for an organisation. Through an empirical study, it was possible to comprehend how a company can transform sustainability into a 
valuable resource, developing routines and processes through time dedicated to sustainability and exploring them financially in a dynamic environment by being more competitive.

In an industry in which sustainability is not seen as something important, Balbo Group managed to stand out through its integrative and innovative strategy with a strong culture focused on sustainability. The intent of the manager in seeing the potential of sustainability to become a valuable resource was also an important factor found in the study. Native, as an organisational innovation, possibly due to several innovations in processes and products, shows how this reconfiguration of resources and efforts turned sustainability into a dynamic capacity. There were no incentive mechanisms to the Balbo Group to take the decisions they made with regard to strategies for sustainability. The effort to place sustainability in the organisation's guidelines, the awareness, policies and organisational culture enabled the company to become sustainable and competitive, providing the value of ambidexterity, which enables the company to focus on sustainability as much as it focuses on the economic factor. The creation of Native is the materialization of this value. The company managed to incorporate the values of sustainability in its core business.

Sustainable development is based on the idea of a network of interacting actors and elements that affect society as a whole. Companies have an important role in this reality by creating sustainability practices that enable the capacity of transforming sustainability in a dynamic strategy.

In order to seek a more sustainable management model, the company has developed dynamic capacities within the economic sphere that focus on efficacy, reduction and reuse of solid wastes, and cogeneration of energy; within the social sphere, the rural workers are assisted with security and quality-of-life programs and within the environmental sphere, the company, through the Green Cane Project ${ }$, has environmental certifications and preserves protected areas by recognising respect for the environment with the production processes of all areas.

Finally, the Native branch and all of the changes demanded by the company's new business were the sources of development of dynamic capacities and adaptation of the company, which shifted from a stable commodity market to a dynamic, increasing market of organic food products.

The Balbo Group has demonstrated innovative sustainable aspects over its trajectory. The company abandoned the traditional model of sugarcane cultivation that involved the use of manual workers and plantations in partnership with landowners in favour of a modern one, which is aimed at, and concerned with, the negative effects of its production.

Limitations appear when there was no empirical way to validate the model in the short term. Future research can emerge when variables, such as budget, engagement level and a comparison between functional area performances can be aggregated to the model.

System theory has made a major contribution in uncovering uncertainties that would be not detected only by describing the manager's interviews. Homeostasis was identified when the system recursively tries to maintain itself in equilibrium - in the case of this company, in a more competitive situation than before.

Acknowledgements The authors are thankful for the insightful comments provided by the editor, Robert L. Flood, and by the anonymous reviewers. The paper also benefited from discussions with participants of the 31 th European Group for Organizational Studies Colloquium (EGOS), 26th Production and Operations Management Society Annual Conference (POMS) and the 59th International Society for the Systems Sciences Annual Meeting (ISSS). The Brazilian National Council for Scientific and Technological Development (CNPq) financially supported this research. 


\section{References}

Ashby WR (1958) Requisite variety and its implications for the control of complex systems. Cybern 1(2):83-99 Ashby, W. R. (2013). Design for a brain: the origin of adaptive behaviour. Springer Science \& Business Media Barney JB (1991) Firm resources and sustained competitive advantage. J Manag 17:203-228

Barreto I (2009) Dynamic capabilities: a review of past research and an agenda for the future. J Manag 36(1):256-280

Bar-Yam Y (2004) Multiscale variety in complex systems. Complexity 9(4):37-45

Batista, L., Ng, I., \& Maull, R. (2013). The homeostasis paradox of new business models. In: The Naples 2013 Forum on Service

Beer, S. (1981). Brain of the firm. 2nd Edition, Chichester: Wiley

Beer S (1984) The viable system model: its provenance, development, methodology and pathology. J Oper Res Soc 35(1):7-25

Beer, S. (1989). The viable system model. Viable Systems Model. Chichester: Wiley

Belico LR, Silveira S (2000) Electric energy for sustainable development. EDUSP, São Paulo

Bergvall-Kåreborn B, Mirijamdotter A, Basden A (2004) Basic principles of SSM modeling: an examination of CATWOE from a soft perspective. Syst Pract Action Res 17(2):55-73

Beske P (2012) Dynamic capabilities and sustainable supply chain management. Int Jnl Phys Dist Log Manage 42:372-387

Birol F (2010) World energy outlook 2010. Int Energy Agency 1(3)

Boscoianu M, Prelipcean G, Lupan M (2018) Innovation enterprise as a vehicle for sustainable development-a general framework for the design of typical strategies based on enterprise systems engineering, dynamic capabilities, and option thinking. J Clean Prod 172:3498-3507

Brundtland GH (1987) Our common future. The world commission on environment and development. Oxford University Press, New York

Burnes B (1996) Managing Change: a strategic approach to Organisational dynamics. Pitman Publishing, London

Caldana, A.C.F, Alves, M.F.R., Cezarino, L.O., \& Liboni, L.B. (2015). Sustainability as a dynamic capability. In: 31th EGOS (European Group of Organization Studies) Colloquium, 2015, Athens

Cezarino LO, Liboni LB, Oliveira MF, Caldana AC (2015) Soft systems methodology and Interdisciplinarity in management education. Syst Res Behav Sci 33(2):278-288

Chakrabarty S, Wang L (2012) The long-term sustenance of sustainability practices in MNCs: a dynamic capabilities perspective of the role of R\&D and internationalization. J Bus Ethics 110:205-217

Checkland P (1981) Systems thinking, systems practice. Wiley, Hoboken

Checkland P, Scholes J (1999) Soft systems methodology: a 30-year retrospective. Wiley, Chichester

Dyllick T, Hockerts K (2002) Beyond the business case for corporate sustainability. Bus Strateg Environ 11(2): 130-141

Ehnert, I. (2009). Sustainable human resources management: A conceptual and exploratory analysis from a paradox perspective. Springer

Eisenhardt KM, Graebner ME (2007) Theory building from cases: opportunities and challenges. Acad Manag J 50(1):25-32

Eisenhardt KM, Martin JA (2000) Dynamic capabilities: what are they? Strateg Manag J 21(10-11):1105-1121

Elkington J (1997) Cannibals with forks: the triple bottom line of 21st century business. Capstone, Oxford

Esty D, Winston A (2009) Green to gold: how smart companies use environmental strategy to innovate, create value, and build competitive advantage. John Wiley \& Sons

Etzion D (2007) Research on organizations and the natural environment, 1992 - present: a review. J Manag 33(4):637-664

Fiksel J (2006) Sustainability and resilience: toward a systems approach. Sustain Sci Pract Policy 2(2)

François C (ed) (2004) International encyclopedia of systems and cybernetics. Walter de Gruyter, Berlin

Gabler, C.B., Richey, R.G., \& Rapp, A. (2015). Developing an eco-capability through environmental orientation and organizational innovativeness, $1-11$

Gebauer H (2011) Exploring the contribution of management innovation to the evolution of dynamic capabilities. Ind Mark Manag 40:1238-1250

Georgiou I (2012) Messing about in transformations: structured systemic planning for systemic solutions to systemic problems. Eur J Oper Res 223(2):392-406

Global Organization Learning and Development Network. (2011). GOLDEN - research handbook. Version $07^{\text {th }}$ december, 2011

Hamin E, Gurran N (2009) Urban form and climate change: balancing adaptation and mitigation in the US and Australia. Habitat Int 33(3):238-245

Harries-Jones P (1995) A recursive vision: Ecological understanding and Gregory Bateson. University of Toronto Press 
Hart SL (1995) A natural-resource-based view of the firm. Acad Manag Rev 20:986-101

Helfat CE (2007) Dynamic capabilities: understanding strategic change in organizations. Blackwell, Malden

Hofmann K H, Theyel G, Wood CH (2012) Identifying firm capabilities as drivers of environmental management and sustainability practices-evidence from small and medium-sized manufacturers. Bus Strateg Environ 21(8): 530-545

Holman, P. (2010). Engaging emergence: turning upheaval into opportunity. Berrett-Koehler Publisher

Liboni-Amui LBL, Jabbour CJC, de Sousa Jabbour ABL, Kannan D (2017) Sustainability as a dynamic organizational capability: a systematic review and a future agenda toward a sustainable transition. J Clean Prod 142:308-322

Lindahl R (2006) The role of organizational climate and culture in the school improvement process: a review of the knowledge base. Educ Leadersh Rev 7(1):19-29

Lubin DA, Esty DC (2010) The sustainability imperative. Harv Bus Rev 88(5):42-50

Martinelli DP, Ventura CAA (2006) Visão Sistêmica e Administração: conceitos, metodologias e aplicações. Saraiva, São Paulo

Mebratu D (1998) Sustainability and sustainable development: historical and conceptual review. Environ Impact Assess Rev 18:493-520

Moallemi EA, Ahamdi A, Afrazeh A, Moghaddam NB (2014) Understanding systemic analysis in the governance of sustainability transition in renewable energies: the case of fuel cell technology in Iran. Renew Sust Energ Rev 33:305-315

Muff K, Kapalka A, Dyllick T (2017) The gap frame - translating the SDGs into relevant national grand challenges for strategic business opportunities. Int J Manag Educ 15 ((2):363-383

Nonaka L, Takeuchi H, Umemoto K (1996) A theory of organizational knowledge creation. Int J Technol Manag 11(7-8):833-845

NOVACANA. (2014). Setor sucroenergético brasileiro supera PIB de mais de 100 paises. Retrieved from: http:/www.novacana.com/n/etanol/marketing/sucroenergetico-supera-pib-100-paises-290514/

Reyers B, Stafford-Smith M, Erb KH, Scholes RJ, Selomane O (2017) Essential variables help to focus sustainable development goals monitoring. Curr Opin Environ Sustain 26:97-105

Russo MV, Fouts PA (1997) A resource-based perspective on corporate environmental performance and profitability. Acad Manag J 40(3):534-559

Schrettle S, Hinz A, Rathje MS, Friedli T (2014) Turning sustainability into action_explaining organizations' sustainability efforts and their impact on firm performance. Int J Prod Econ 147:73-84

Senge, P. M. (1990). A quinta disciplina: arte, teoria e prática da organização de aprendizagem. Best Seller

Shuen A, Feiler PF, Teece DJ (2014) Dynamic capabilities in the upstream oil and gas sector: managing next generation competition. Energ Strat Rev 3:5-13

Spetic W, Marquez P, Kozak R (2012) Critical areas and entry points for sustainability-related strategies in the sugarcane-based ethanol industry of Brazil. Bus Strateg Environ 21(6):370-386

Stokes, P. A. (2004). Identity as a cybernetic process, construct and project. In A Paper presented to "Governance \& Public Administration," a Conference by the Cybernetics Society and Metaphorum, London School of Economics, 3-4

Teece DJ (2007) Explicating dynamic capabilities: the nature and microfoundations of (sustainable) enterprise performance. Strateg Manag J 28(13):1319-1350

Teece DJ, Pisano G, Shuen A (1997) Dynamic capabilities and strategic management. Strateg Manag J 18(7):509-533

UNGC (2015). Sustainable Development Goals. Retrieved from: https://www.unglobalcompact.org/what-isgc/our-work/sustainable-development/sdgs

UNGC (2018). Global Opportunity Report. Retrieved from: https://www.unglobalcompact. org/docs/publications/Global_Opportunity_Report_2018.pdf

United Nations (2017). The sustainable development goals report. Retrieved from: https://unstats.un. org/sdgs/files/report/2017/TheSustainableDevelopmentGoalsReport2017.pdf

Werbach A (2010) Estratégia para a sustentabilidade: uma nova forma de planejar sua estratégia empresarial. Elsevier, Rio de Janeiro

Yigitcanlar T, Teriman S (2015) Rethinking sustainable urban development: towards an integrated planning and development process. Int J Environ Sci Technol 12(1):341-352

Zhao P (2010) Sustainable urban expansion and transportation in a growing megacity: consequences of urban sprawl for mobility on the urban fringe of Beijing. Habitat Int 34(2):236-243

Zollo M, Winter SG (2002) Deliberate learning and the evolution of dynamic capabilities. Organ Sci 13(3):339-351 